\title{
An Analysis of Vietnamese Bank Productivity Change in the Time of Restructuring
}

\author{
Tha Hien TO'1, Phuong Thanh LE ${ }^{2}$
}

Received: August 01, 2020 Revised: October 05, 2020 Accepted: October 15, 2020

\begin{abstract}
Commercial banks play an important role as the main source of funding in the transition process of Vietnam as a market economy. As a result, enhancing the efficiency and productivity of Vietnamese banks can decrease the lending cost for individuals and enterprises. This study is to measure and analyze the productivity change of Vietnamese banking system in different ownership cohorts and sources of this change during the period of restructuring (2011-2019). The Hicks-Moorsteen total factor productivity index is utilised to measure the productivity change and to identify the sources of this change. For an empirical analysis, the data of 28 Vietnamese commercial banks from 2011 to 2018 is collected from their financial statements including balance sheets and income statements. The results show an increase of Vietnamese bank productivity due to the technological progress. While foreign and joint-venture banks are the most advanced cohort, stateowned banks have the lowest rate of productivity growth. The restructuring program negatively impacts scale efficiency and this measure attributes to a decline in the overall efficiency of the banks. We also found that state-owned commercial banks are the most efficient group in the sense that they can achieve the maximal level of revenue from a given amount of expense.
\end{abstract}

Keywords: Total Factor Productivity, Hicks-Moorsteen Index, Bank Restructuring, Vietnam

JEL Classification Code: D24, G21, G65

\section{Introduction}

In emerging economies, the banking sector dominates the financial system that is still in its infancy stage and is vulnerable to external shocks (Claessens, Ghosh, and Mihet, 2013). Rapid credit growth to foster economic growth in the context of poor risk management can lead to banking distress in emerging economies (Duong, Phan, Hoang, and Vo, 2020; Llewellyn, 2002). Several problems can emerge from these crises including illiquidity, nonperforming loans and credit crunch (Ariff and Can, 2009; Hakenes and Schnabel, 2010). To solve these problems,

${ }^{1}$ First Author and Corresponding Author. Senior Lecturer, Dean of Political Economy Faculty, Le Quy Don Technical University, Vietnam [Postal Address: 236 Hoang Quoc Viet Street, Cau Giay District, Hanoi, 11355, Vietnam] Email: tohientha.mta@gmail.com ${ }^{2}$ Lecturer, Faculty of Business and Finance, Vietnam Maritime University, Haiphong, Vietnam. E-mail: phuonglt@vimaru.edu.vn

(c) Copyright: The Author(s)

This is an Open Access article distributed under the terms of the Creative Commons Attribution Non-Commercial License (https://creativecommons.org/licenses/by-nc/4.0/) which permits unrestricted non-commercial use, distribution, and reproduction in any medium, provided the original work is properly cited. the governments have to implement a number of solutions to mitigate the bad effect of banking distress. There are two types of solutions, so-called stock and flow solutions. The first are those pointing to resolve accumulated losses. For example, governments react to banking crises by shutting down unviable banks, removing bad loans to asset management companies, requiring capital injection, nationalising weak banks and implementing compulsory purchases and transferring assets to healthier banks (Berger and Turk-Ariss, 2015; Williams and Nguyen, 2005). The second cohort of restructuring measures is to protect banks from generating losses and can only be implemented when these aforementioned stock solutions are completed. Different flow measures include replacing underperformed managers, innovating banking services, issuing new banking standards (for instance, new regulations on capital adequacy, loan classification and supervision), and allowing majority foreign ownership.

These restructuring measures are expected to impact bank performance in different ways. Ariff and Can (2009) found that East Asian banking systems improved their efficiency during the restructuring period but restructured banks were not more efficient than their unrestructured counterparts. 
While recapitalisation and reprivatisation brought about a positive impact on the bank performance, other measures including bank closure, mergers and ease of entry for more foreign bank participation were insignificant. Williams and Nguyen (2005) examined the impact of liberalisation measures in Southeast Asian countries on the bank performance during the 1999-2003 period that was characterised by financial deregulation, crisis and restructuring programs. The results provide economic justification for the bank privatisation program when this policy enhanced bank efficiency. Foreign acquisition appeared to be cherry-pick but did not lead to any improvement in the bank performance and this measure is expected to have performance effect in the longer duration. Hsiao, Chang, Cianci, and Huang (2010) investigated the impact of Taiwanese restructuring programs on bank operating efficiency between 2000 and 2005, and found that the bank efficiency improved in the post-reform period due to enhanced risk management and compliance with changes in banking regulations.

Williams (2012) tests if the restructuring program could influence bank efficiency and market power using the data of Latin American banks between 1985 and 2010. Utilising a difference-in-difference approach, the result supports a positive impact of privatisation program on bank performance while foreign entry was ineffective. Pestana and Williams (2013) examines the effect of foreign acquisition on Mexican local banks following the legislative reforms as measures of bank restructuring programs. They find an insignificant influence of foreign acquisition whereas consolidation of local banks improved long-term efficiency.

The theories of firm operation consider efficiency as a component of total production productivity (TFP) that includes efficiency and technology. As a result, the performance of a firm (or bank) is determined by two factors, the quality of management (efficiency) and science-based methods to produce products/services (technology). Even though there are numerous studies on the impact of restructuring measures on bank performance, but these studies only focus on bank efficiency. Using efficiency measures in studies of firm (bank) performance must be based on an assumption that there is no technological change during the considered period (Linna, 1998). This assumption cannot be held during the restructuring time due to the fact that measures to restructure the banking sector require banks to innovate their production processes and technology. Merger and acquisition (M\&A), for instance, is a common measure that requires weak, small banks to be a part of and adopt the more advanced technology from sound, large banks (Altunbaş and Marqués, 2008). Furthermore, closure of unviable banks is also one of solutions promoting the banking technology when the most backward units are eliminated (Calderon and Schaeck, 2016). Last but not the least, in the perspective of emerging market economies where the foreign investors can take part in domestic banks as major shareholders, modern banking technology and expertise from developed countries are imported and applied, resulting in an advancement of technology in the banking industry of host countries (Hasan and Xie, 2013). The mentioned issues raise the importance of including TFP measure rather than efficiency measure in examining the impact of banking restructuring programs on bank performance.

To fill the above gaps, this paper uses Hicks-Moorsteen TFP index to measure the TFP change of Vietnamese banking sector as a whole and in different ownership types and points out the sources of these changes during the time of restructuring (2011-2019). The results show an improvement of bank productivity due to technical progress under the condition of efficiency deterioration. Scale efficiency is the source of overall efficiency decline while mix and technical efficiency are seemingly unchanged.

The structure of this study is organised as below. The next section is an overview of Vietnamese banking sector in the 2011-2019 period. The Section 3 of methodology provides the theoretical framework of productivity indexes and specifically the Hicks-Moorsteen index. The data and results providing an empirical analysis of the productivity change in Vietnamese banking sector and its sources of change are presented in Section 4 and Section 5, respectively. Lastly, Section 6 provides several important concluding remarks.

\section{Vietnamese Banking Sector in the Time of Restructuring (2011-2019)}

Vietnam became an official member of the World Trade Organisation (WTO) in 2007 and this event marked a turning point in liberalising this country' banking system. Accordingly, foreign owned banks were allowed to open and overseas investors could take part in the domestic banks as minor shareholders. State-owned banks had to be privatised to improve their competitiveness and efficiency. All domestic banks increased equity to fulfil the capital requirements from the central bank (the State Bank of Vietnam - SBV) and expanded their scope of operations and banking services (Bui, 2020).

The Government conducted the expansionary monetary policy to foster its economy and lending regulations were eased to support credit growth (Nguyen and Dang, 2020). Consequently, the volume of credit surged by $35 \%$ annually on an average from 2007 to 2011 . The credit accounted for $78 \%$ of GDP in 2006 before rising to the top at 112.8\% in 2009. In the infant and shallow financial system like one that of Vietnam, rapid credit growth may generate bad loans due to low quality of risk management and poor framework of regulation and supervision (Pincus, 2009). The rate of non-performing loans 
is only $1.55 \%$ in 2006 but jumped to a significantly higher level at 11.8\% in 2011 (World Bank, 2014).

To avoid a collapse of the Vietnamese banking system, the Government has conducted a long-run restructuring program lasting from 2011 to 2019. The restructuring program is to consolidate the banking sector and focuses on three groups of solutions, including (1) solutions to improve banks' financial capability; (2) solutions to renovate the system of banking management in accordance with international standards; and (3) solutions to restructure bank operations in a safe and sustainable manner (Dang, 2020; World Bank, 2019). It is worth noting that these groups of solutions not only solve short-term problems of the banking system but also ensure its safety and sustainable development in the long-term.

The first group of solutions aimed at making banks healthy and improving their financial capacity. Stemming from the macroeconomic turbulence and poor risk management, bad loans increased sharply since the end of 2011. Moreover, most of the bad loans were not identified, recognised, classified by the proper banking standards. In September of 2012, the NPL ratio estimated by the State Bank of Vietnam (SBV) reached $17.21 \%$, which was much higher than the rate announced by the individual banks (World Bank, 2014). In this situation, the urgent task of the SBV was to control credit quality and handle bad loans. Many solutions were developed and implemented synchronously such as reviewing and issuing new regulations on loan classification and loanloss provisioning. Besides, an asset management company (VAMC) was established. Commercial banks must sell bad debts to VAMC to ensure the NPL ratio did not exceed 3\%. In return, commercial banks will receive special bonds that can be used to refinance from the SBV. Parallelly, for resolving bad debts, the SBV required banks to increase their charter capital to retain more profits.

The second group of solutions aimed at renovating bank governance as per the international practices and standards. This task was implemented in many aspects such as developing new business strategies; raising the standards of management competencies; developing a risk management system based on the principles of the Basel Committee; renovating and improving the quality of the internal control and auditing system and encouraging banks to list in the stock market.

The last group of solutions were to innovate banking services through reducing loans on risky businesses such as property and stock; diversifying asset items and employing fin-tech to reduce operating cost and enhance the scope of bank operations.

The 2011-2019 period witnessed many measures to consolidate the Vietnamese banking sector. The aforementioned measures made a great impact on the commercial banking system in the short-term as well as in long-term. Restructuring measures require commercial banks to comply with stricter regulations on lending, reducing credit growth rate and resolving bad loans. Consequently, the performance of banks is significantly influenced, therefore, examining the impact of the restructuring measures on the banking system is necessary to shed light on these measures' effectiveness.

\section{Methodology}

Precise measurement of total factor productivity change and its components are necessary for making economic and business decisions (O'Donnell, 2012). There are many TFP indexes but the indexes which can be expressed as the ratio of aggregate output quantity index to an input aggregate quantity index and satisfies regular axioms (monotonicity, identity, homogeneity, commensurability and proportionality), are considered to be multiplicatively complete (Balk, 2012). The multiplicatively complete TFP indexes can be decomposed into measures of technical changes and a number of efficiency changes. Malmquist TFP index is incomplete but commonly utilized in literature due to its easy decomposition into technical and efficiency change (O'Donnell, 2010). While other multiplicatively complete TFP indexes require the data of prices or cost to calculate (Fisher and Törnqvist index), Hicks-Moorsteen index does not rely on these types of information. Consequently, unlike other indexes, the accuracy and availability of these data can not impact the results of Hicks-Moorsteen index. In this study, we choose the Hicks-Moorsteen index to measure the productivity change of Vietnamese banking sector.

Let $x_{t} \in \mathbb{R}_{+}^{M}$ and $q_{t} \in \mathbb{R}_{+}^{N}$ denote the input and output quantity vectors respectively for the firm in the period $t$. Based on these quantity vectors, the scalar input and output quantity aggregates denoted $Q_{t} \equiv Q(q)$ and $X_{t} \equiv Q(x)$, where $Q($.$) and X($.$) are aggregate functions. The productivity of a$ firm in the period $t$ is defined as:

$$
T F P_{t}=\frac{Q_{t}}{X_{t}}
$$

The TFP index measures the change of productivity between the periods $s$ and $t$ is:

$$
T F P I_{s t}=\frac{T F P_{t}}{T F P_{s}}=\frac{Q_{t} / Q_{s}}{X_{t} / X_{s}}
$$

The input and output distance functions proposed by Shephard (1953) are employed and described as below:

$$
D_{I}^{t}(x, q)=\sup \{\rho>0:(x / \rho, q) \in T\}
$$




$$
D_{O}^{t}(x, q)=\inf \left\{\delta>0:(x, q / \delta) \in T^{t}\right\}
$$

where $D_{I}^{t}(x, q)$ and $D_{O}^{t}(x, q)$ are input and output distance functions respectively and $T=\{(x, q): x$ can produce $q$ in period $t\}$ denotes the production set in the $t$ period.

The equation to calculate Hicks-Moorsteen index is as below:

$\operatorname{TFPI}_{s t}^{H M}=\left(\frac{D_{O}^{s}\left(x_{s}, q_{t}\right) D_{O}^{t}\left(x_{t}, q_{t}\right) D_{I}^{s}\left(x_{s}, q_{s}\right) D_{I}^{t}\left(x_{s}, q_{t}\right)}{D_{O}^{s}\left(x_{s}, q_{s}\right) D_{O}^{s}\left(x_{t}, q_{s}\right) D_{I}^{s}\left(x_{t}, q_{s}\right) D_{I}^{t}\left(x_{t}, q_{t}\right)}\right)^{1 / 2}$

\section{Measures of efficiency}

To identify the sources of Hicks-Moorsteen TFP change, O'Donnell (2012) decomposes this TFP into technical components and three different measures of efficiency, including technical efficiency, scale and mix efficiency. In Figure 1, the curve passing the points B, D and C presents the frontier of a mix-restricted production possibility set, containing aggregates of input and output vectors which can be written as scalar multiples of $x_{t}$ and $q_{t}$. Holding input and output mixes fixed, the mix-restricted frontier can be viewed as the frontier of single-input single-output production. Under the condition of output orientation, the measures of efficiency can be described as:

$$
O T E_{t}=\frac{Q_{t}}{\bar{Q}_{t}}=\frac{\text { slope } O A}{\text { slope } O C} \text { (output-oriented technical }
$$

efficiency)

$$
O M E_{t}=\frac{\bar{Q}_{t}}{\hat{Q}_{t}}=\frac{\text { slope } O C}{\text { slope } O V} \text { (output-oriented mix }
$$

efficiency)

$$
\operatorname{ROSE} E_{t}=\frac{\hat{Q}_{t} / X_{t}}{Q_{t}^{*} / X_{t}^{*}}=\frac{\text { slope } O V}{\text { slope } O E} \text { (residual output-oriented }
$$

scale efficiency)

Output-oriented technical efficiency is a measure of the vertical distance from point A to point C. In terms of slopes of rays through the origin, OTE $E_{t}=$ slopeOA/slopeOC and this measure is equivalent to the ratio of TFP at point A ( $Q t)$ $X t_{-}$observed TFP) to TFP at point C $\left(\bar{Q}_{t} / X_{t}{ }_{-}\right.$the possible maximum TFP while holding the input and output vector mixes fixed).

When the restrictions on the input mix and/or output mix is relaxed, the input-output combinations will be expanded and this leads to the establishment of an unrestricted production frontier which envelops all feasible mix-restricted frontiers. The unrestricted frontier passes through points $U$, $\mathrm{E}$ and $\mathrm{V}$ in Figure 1. If we remove the restrictions on output mix, the firm A can further expand its output via moving from

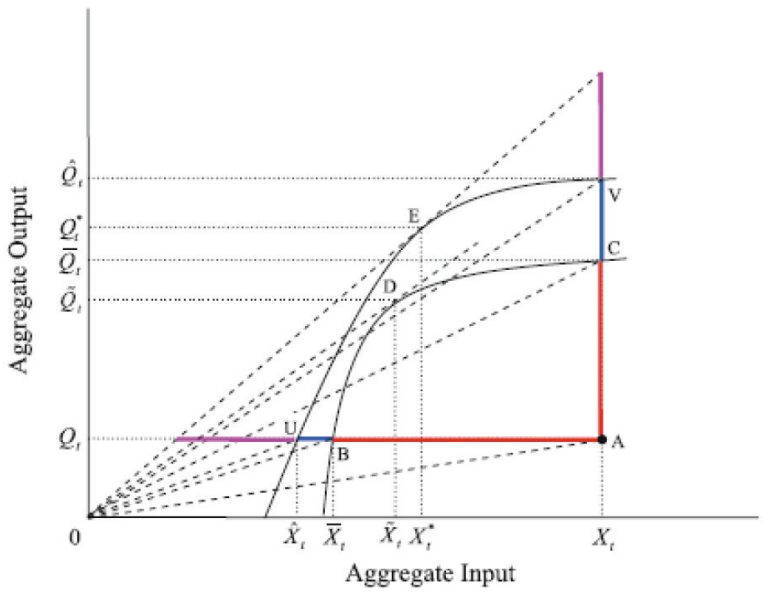

Figure 1: Different measures of efficiency

Note: Adapted from O’Donnell (2012), page 261

point $\mathrm{C}$ to point $\mathrm{V}$ in Figure 1. Output-oriented mix efficiency $\left(O M E_{t}\right)$ is the ratio of TFP at point $\mathrm{C}$ and TFP at point $\mathrm{V}$ and equal to $\frac{\bar{Q}_{t} / X_{t}}{\hat{Q}_{t} / X_{t}}$ or $\frac{\bar{Q}_{t}}{\hat{Q}_{t}}$.

Even after achieving both technical and mix efficiency, the firm A can still enhance their TFP by moving from point $\mathrm{V}$ to point $\mathrm{E}$ where a ray through the origin is tangent to the unrestricted frontier and the TFP at point $\mathrm{E}$ is maximum. Moving from point $\mathrm{V}$ to point $\mathrm{E}$ can be conducted via optimising the output scale. Residual output-oriented scale efficiency $\left(R O S E_{t}\right)$ is the ratio of TFP at point V to TFP at point $\mathrm{E}$ and equal to $\frac{\hat{Q}_{t} / X_{t}}{Q_{t}^{*} / X_{t}^{*}}$.

Based on these above measures of efficiency, the outputoriented decomposition of Hicks-Moorsteen TFP in the period $t$ are:

$$
\mathrm{TFP}_{\mathrm{t}}=T F P_{t}^{*} \times \mathrm{OTE}_{\mathrm{t}} \times \mathrm{OME}_{\mathrm{t}} \times \mathrm{ROSE}_{\mathrm{t}}
$$

where $T F P_{t}^{*}$ is the maximum TFP possible using any technically feasible inputs and outputs.

\section{Decomposition of TFP change}

The TFP index that compares the change of productivity between periods $s$ and $t$ can be decomposed as:

$T F P I_{s t}=\underbrace{\left(\frac{T F P_{t}^{*}}{T F P_{s}^{*}}\right)}_{\text {Technical change }} \times \underbrace{\left(\frac{O T E_{t}}{O T E_{s}}\right)\left(\frac{O M E_{t}}{O M E_{s}}\right)\left(\frac{R O S E_{t}}{R O S E_{s}}\right)}_{\text {Measures of efficiency change }}$ 


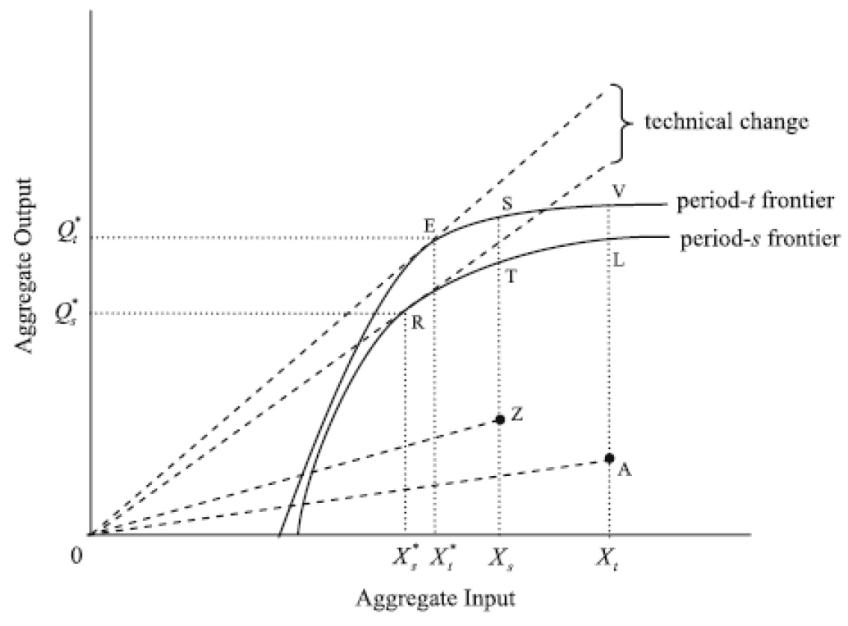

Figure 2: Dynamic changes of TFP productivity and its components

Note: Adapted from O'Donnell (2012), page 264

The first ratio in parentheses on the right hand side of equation (10) demonstrates technical change via comparing the maximum TFP between periods $s$ and $t$. The illustration of technical change is presented in Figure 2. Points $\mathrm{Z}$ and $\mathrm{A}$ in this figure present two input-output combinations of a firm at the period $s$ and $t$ respectively, when points $\mathrm{R}$ and E represent the maximum TFP in each period. Accordingly, the measure of technical change in equation (10) is $\frac{T F P_{t}^{*}}{T F P_{s}^{*}}=\frac{\text { slopeOE }}{\text { slopeOR }}$.

Measures of output-oriented efficiency changes including technical efficiency change, mix efficiency change, and residual scale efficiency change are the remaining ratios in the right-hand side of equation (10).

In this study, DPIN software developed by Professor O'Donnell from University of Queensland, Australia is utilised to estimate Hicks-Moorsteen TFP index and its components with Vietnamese bank data.

\section{Data}

To measure the productivity of Vietnamese banks using HicksMoorsteen TFP index, input variables $\left(x_{t}\right)$ and output variables $\left(q_{t}\right)$ should be identified. According to Das and Ghosh (2006), based on bank functions, there are three approaches to bank inputs and outputs. The first approach, the so-called production approach, views banks as providers of services to customers. Physical variables including labour, material, working space and information system are possible input variables under this approach. Meanwhile, the outputs presenting the services are the number of types of transactions and documents processed and they are commonly proxied by the number of deposit and loan accounts. The production approach has been widely utilised to study the efficiency of bank branches. With the intermediation approach, financial institutions such as banks intermediate funds from savers to investors and intermediation services are generated via the collections of deposits and other liabilities before applying in interest-earned assets (e.g, loans, securities and other investments). Under this approach, operating and interest expenses are considered as inputs whereas loans and other assets are treated as outputs. Lastly, the operating approach (or income-based approach/profit approach) considers banks as business units. The final objective of these units is to maximise profit via generating revenue from the total cost incurring for running the business. Accordingly, the interest and non-interest expenses are behaved as inputs while interest and non-interest revenue are treated as outputs.

To measure bank efficiency, it is crucial to identify the appropriate approach to inputs and outputs. And this identification has to depend on the particular circumstance of the banking sector. During the restructuring period (2011-2019), the credit growth of Vietnamese banks has been curbed and the most important objective is to reduce NPLs and improve bank profit. As a result, the operating approach (or profit approach) to inputs and outputs has been chosen in this study.

Following Das and Ghosh (2006), Hsiao, Chang, Cianci, and Huang (2010) and Le, Harvie, Arjomandi, and Borthwick (2019), the inputs of operating approach include interest and non-interest expenses while the outputs are interest and noninterest revenues. Interest expenses include expenses for deposits and other borrowed money while non-interest expenses are the sum of service charges, salaries and other expenses. On the other side, interest revenues from intermediation services include interest payments from the borrowers and income from holding government or corporate bonds. Non-interest revenue consists of service charges on settlements, transactions, income from renting and fiduciary activities, foreign currency business and other operating incomes.

To analyse the impact of restructuring program on Vietnamese bank performance, the data of 28 banks for the period 2011 to 2018 was collected via their financial statements. Of which, there are 20 private banks (commonly called the joint stock banks, JSBs), four state-owned commercial banks (SOCBs) and four foreign/joint-venture banks (FJVBs). The big-four SOCBs contribute to $48 \%$ of the total banks' assets while only a minority of $10 \%$ belongs to the FJVBs (Le, Harvie, Arjomandi, and Borthwick, 2019). Table 1 describes input/output variables used in this study. It is clear that the main source of bank revenue is from intermediation services and this type of income is approximately five times higher than that from all other banking activities. 
Table 1: Summary of Inputs and Outputs (in mil. VND)

\begin{tabular}{|c|c|c|c|c|}
\hline & Mean & Std. Dev & Min & Max \\
\hline \multicolumn{5}{|l|}{ Inputs } \\
\hline Interest expense & $7,376,792$ & $10,046,757$ & 76,860 & $55,118,154$ \\
\hline Non-interest expense & $3,474,783$ & $4,886,823$ & 72,594 & $27,366,051$ \\
\hline \multicolumn{5}{|l|}{ Outputs } \\
\hline Interest revenue & $12,048,171$ & $16,899,097$ & 293,987 & $94,071,333$ \\
\hline Non-interest revenue & $1,824,172$ & $2,928,863$ & 11,910 & $15,543,525$ \\
\hline
\end{tabular}

\section{Results}

This section presents empirical results of productivity and efficiency changes of the Vietnamese banking system over a period from 2011 to 2018, using the operating approach to bank inputs and outputs. In Table 2 output-oriented efficiency measures including technical efficiency (OTE), scale efficiency (ROSE) and mix efficiency (OME) are illustrated for three types of bank ownership and in three selected years (2012, 2015, and 2018). A bank having technical efficiency estimates equal to unity indicates that it is located on the production frontier and understood to be relatively efficient. In contrast, a below-unity estimate means that its location is under the frontier and hence it is inefficient. A bank can be technically efficient and its scale and mix efficiency less than unity indicates that it is still on the frontier, but at a relatively unproductive point.

Table 2 shows that there are no banks achieving all three types of efficiency (technical, scale and mix efficiency). However, there are a number of banks achieving both technical and mix efficiency, e.g. Bao Viet bank in 2012 or VID Public bank in 2018.

In terms of output-oriented technical efficiency, the results support the outperformance of public banks when they are all located on the frontier in three selected years with the value of technical efficiency equal to one. This fact advocates that SOCBs can generate the largest revenue from a given amount of expense compared to their private, foreign and joint-venture rivals. With regard to scale efficiency, the finding shows no banks can operate at the optimum size (see Table 2).

In terms of coordinating different inputs/outputs in a production process, the results reveal the increasing number of banks that can achieve mix efficiency during the restructuring period, from 8 in 2012 to 11 in 2015, and to 21 in 2018. This result supports the effectiveness of restructuring solutions that aim to diversity bank activities and reduce the dependence on intermediation services.

Table 3 presents the estimates of annual aggregate efficiency during the 2011-2018 period. The results show that except the year 2013, all SOCBs are the bestpractice banks when locating on the production frontier with the technical efficiency score equal to unity. These banks exert an outperformance in comparison with other bank groups including JSBs and FJVBs due to the larger size and advantages of privatisation which took place during 2006-2010 (Batten and Vo, 2019; Le, Harvie, Arjomandi, and Borthwick, 2019). Regarding ROSE, this is obvious that the value of scale efficiency decreases from 2012 and public banks are the most affected group when their value of scale efficiency declined to 0.1570 in 2018 from 0.6805 in 2011. This reality can be explained by a shift of monetary policy from being expansionary to contractionary. Accordingly, intermediation services are limited when the rate of credit growth is stringently controlled by the SBV.

Table 4 presents the TFP change and its component changes (technology and efficiency) of Vietnamese banking sector during the restructuring period. Additionally, components of efficiency changes (technical, scale and mix efficiency) are also reported. An average value of the HicksMoorsteen TFP index or its component index is greater than the unity, indicates an improvement or a regress if this value is less than one.

The average value of the TFP index, over the years 2011-2018 and for all types of ownership, stands at 1.0789 indicating an improvement of the Vietnamese bank performance at a rate of $7.89 \%$ annually. Several reasons behind this progress consists of (1) effective NPL solving, (2) diversifying the banking services which resulted in a high level of mix efficiency, and (3) applying new technologies such as internet banking, and block chain. However, the extent of productivity growth is distinctive among bank groups. Specifically, the foreign and joint-venture banks are the most progressive with the productivity growth rate by $14.7 \%$ /year. This is because these banks are less influenced by NPL and the diversity of their banking product offerings. State-owned banks experience an insignificant growth of productivity when the rate is only $1.8 \%$ per year. 
Table 2: Output-oriented efficiency measures for Vietnamese individual banks in 2012, 2015 and 2018

\begin{tabular}{|c|c|c|c|c|c|c|c|c|c|}
\hline \multirow{2}{*}{ Bank } & \multicolumn{3}{|c|}{2012} & \multicolumn{3}{|c|}{2015} & \multicolumn{3}{|c|}{2018} \\
\hline & OTE & ROSE & OME & OTE & ROSE & OME & OTE & ROSE & OME \\
\hline \multicolumn{10}{|l|}{ Joint Stock Banks (Private banks) } \\
\hline Asia Commercial Bank & 0.8113 & 0.6685 & 0.9981 & 0.8507 & 0.6591 & 0.9991 & 0.7709 & 0.6361 & 1 \\
\hline Bao Viet Bank & 1 & 0.3974 & 1 & 1 & 0.599 & 1 & 1 & 0.7322 & 1 \\
\hline $\begin{array}{l}\text { Vietnam Export - Import } \\
\text { Commercial Bank }\end{array}$ & 0.8758 & 0.907 & 0.9768 & 0.8717 & 0.8083 & 0.9836 & 0.6959 & 0.8407 & 1 \\
\hline Ho Chi Minh Development Bank & 1 & 0.4223 & 0.9785 & 0.8393 & 0.5656 & 0.9634 & 0.7573 & 0.8995 & 0.9859 \\
\hline Lien Viet Bank & 1 & 0.6803 & 0.9546 & 0.8951 & 0.683 & 0.991 & 0.7964 & 0.6532 & 1 \\
\hline Military Commercial Bank & 1 & 0.5965 & 0.9831 & 0.9022 & 0.4238 & 0.9083 & 0.8764 & 0.3652 & 0.9712 \\
\hline Maritime Commercial Bank & 1 & 0.7448 & 0.7957 & 1 & 0.3222 & 0.9663 & 1 & 0.5434 & 1 \\
\hline Nam A Bank & 0.9031 & 0.7147 & 0.9669 & 0.7597 & 0.8857 & 1 & 0.9607 & 0.9351 & 1 \\
\hline Sacombank & 0.9002 & 0.7112 & 0.9888 & 0.8315 & 0.6928 & 0.9952 & 0.785 & 0.2422 & 0.9712 \\
\hline Dong Nam A Bank & 0.7212 & 0.6346 & 0.8222 & 0.8381 & 0.4888 & 1 & 0.9544 & 0.4549 & 1 \\
\hline Saigon commercial bank & 0.9033 & 0.7518 & 1 & 1 & 0.8806 & 0.9236 & 0.7233 & 0.8684 & 1 \\
\hline $\begin{array}{l}\text { Vietnam Technological and } \\
\text { Commercial Bank }\end{array}$ & 1 & 0.2733 & 0.9724 & 1 & 0.1499 & 0.9731 & 1 & 0.4238 & 1 \\
\hline $\begin{array}{l}\text { Vietnam International Commercial } \\
\text { Bank }\end{array}$ & 1 & 0.7358 & 0.8623 & 1 & 0.4965 & 0.961 & 1 & 0.5864 & 1 \\
\hline Vietnam Prosperity Bank & 1 & 0.6329 & 0.923 & 1 & 0.2324 & 1 & 1 & 0.1617 & 1 \\
\hline An Binh Bank & 0.6791 & 0.7021 & 0.9943 & 0.7066 & 0.7499 & 0.9937 & 1 & 0.1753 & 1 \\
\hline Kien Long Bank & 0.8207 & 0.8138 & 0.986 & 0.8478 & 0.832 & 0.8947 & 0.7214 & 0.8656 & 1 \\
\hline National Citizen Bank & 0.7113 & 0.7227 & 0.9943 & 0.7949 & 0.6577 & 0.9738 & 0.5577 & 0.9458 & 1 \\
\hline Petrolimex commercial bank & 0.9879 & 0.7386 & 0.9572 & 0.8629 & 0.9361 & 1 & 0.8418 & 0.7998 & 1 \\
\hline Saigon - Hanoi Commercial Bank & 0.9407 & 0.8238 & 0.8849 & 1 & 0.6719 & 0.9827 & 1 & 0.6607 & 0.9799 \\
\hline Vietnam Public commercial bank & 1 & 0.7125 & 1 & 0.7437 & 0.6841 & 0.9901 & 0.8435 & 0.4677 & 0.9968 \\
\hline \multicolumn{10}{|l|}{ State-owned commercial banks } \\
\hline Bank for Foreign Trade of Vietnam & 1 & 0.1831 & 0.9429 & 1 & 0.1317 & 1 & 1 & 0.1797 & 1 \\
\hline Bank for Industry and Trade & 1 & 0.1729 & 1 & 1 & 0.1329 & 1 & 1 & 0.1931 & 0.9607 \\
\hline $\begin{array}{l}\text { Bank for Investment and } \\
\text { Development }\end{array}$ & 1 & 0.6586 & 1 & 1 & 0.2779 & 1 & 1 & 0.1431 & 1 \\
\hline $\begin{array}{l}\text { Bank for Agriculture and Rural } \\
\text { Development }\end{array}$ & 1 & 0.169 & 0.9775 & 1 & 0.2488 & 0.9517 & 1 & 0.112 & 1 \\
\hline \multicolumn{10}{|l|}{ Foreign and Joint-venture banks } \\
\hline $\begin{array}{l}\text { Hongkong Shanghai Banking } \\
\text { Corporation }\end{array}$ & 1 & 0.4961 & 1 & 1 & 0.3401 & 1 & 1 & 0.7131 & 1 \\
\hline Shinhan Bank & 1 & 0.8795 & 1 & 0.8846 & 0.5956 & 1 & 0.8654 & 0.9377 & 0.9998 \\
\hline Indovina Bank & 0.9254 & 0.7954 & 0.9416 & 0.7341 & 0.7439 & 0.9305 & 0.8327 & 0.8195 & 1 \\
\hline VID Public Bank & 1 & 0.0198 & 1 & 1 & 0.0834 & 1 & 1 & 0.1442 & 1 \\
\hline
\end{tabular}

Notes: OTE is output-oriented technical efficiency; ROSE is residual output-oriented scale efficiency and OME is output-oriented mix efficiency. 
Table 3: Efficiency components (technical, scale and mix efficiency)

\begin{tabular}{|c|c|c|c|c|c|c|c|c|c|c|c|c|}
\hline \multirow{2}{*}{ Year } & \multicolumn{3}{|c|}{ JSB } & \multicolumn{3}{c|}{ SOCB } & \multicolumn{3}{c|}{ FJVB } & \multicolumn{3}{c|}{ ALL } \\
\cline { 2 - 14 } & OTE & ROSE & OME & OTE & ROSE & OME & OTE & ROSE & OME & OTE & ROSE & OME \\
\hline 2011 & 0.9346 & 0.9097 & 1.0000 & 1.0000 & 0.6805 & 1.0000 & 0.9334 & 0.8411 & 1.0000 & 0.9438 & 0.8671 & 1.0000 \\
\hline 2012 & 0.9127 & 0.6692 & 0.9520 & 1.0000 & 0.2959 & 0.9801 & 0.9814 & 0.5477 & 0.9854 & 0.9350 & 0.5985 & 0.9608 \\
\hline 2013 & 0.9382 & 0.6558 & 0.9758 & 0.9962 & 0.2356 & 0.9863 & 0.9810 & 0.5101 & 0.9967 & 0.9526 & 0.5749 & 0.9803 \\
\hline 2014 & 0.9174 & 0.7343 & 0.9663 & 1.0000 & 0.2320 & 0.9904 & 0.9957 & 0.4965 & 0.9950 & 0.9404 & 0.6286 & 0.9738 \\
\hline 2015 & 0.8872 & 0.6210 & 0.9750 & 1.0000 & 0.1978 & 0.9879 & 0.9047 & 0.4408 & 0.9826 & 0.9058 & 0.5348 & 0.9779 \\
\hline 2016 & 0.9227 & 0.6091 & 0.9774 & 1.0000 & 0.2590 & 1.0000 & 0.9308 & 0.6052 & 0.9995 & 0.9349 & 0.5585 & 0.9838 \\
\hline 2017 & 0.8346 & 0.5281 & 0.9631 & 1.0000 & 0.1461 & 0.9896 & 0.8964 & 0.4848 & 0.9995 & 0.8671 & 0.4674 & 0.9721 \\
\hline 2018 & 0.8642 & 0.6129 & 0.9953 & 1.0000 & 0.1570 & 0.9902 & 0.9245 & 0.6536 & 1.0000 & 0.8922 & 0.5536 & 0.9952 \\
\hline
\end{tabular}

Notes: OTE is output-oriented technical efficiency; ROSE is residual output-oriented scale efficiency and OME is output-oriented mix efficiency.

Table 4: Vietnamese bank total factor productivity changes and its components in the 2011-2018 period

\begin{tabular}{|c|c|c|c|c|c|c|c|c|}
\hline & 2012 & 2013 & 2014 & 2015 & 2016 & 2017 & 2018 & Mean \\
\hline \multicolumn{9}{|c|}{ Joint Stock Banks } \\
\hline$\triangle \mathrm{TFP}$ & 1.0288 & 1.2680 & 0.9720 & 0.9836 & 1.1518 & 1.1284 & 1.0091 & 1.0774 \\
\hline$\Delta$ Tech & 1.1652 & 1.2795 & 1.2057 & 1.1947 & 1.1021 & 1.3420 & 0.8813 & 1.1672 \\
\hline$\Delta \mathrm{Eff}$ & 0.9460 & 1.0611 & 0.9242 & 0.8363 & 1.0592 & 0.8820 & 1.2016 & 0.9872 \\
\hline$\triangle \mathrm{OTE}$ & 0.9800 & 1.0349 & 0.9821 & 0.9713 & 1.0481 & 0.9068 & 1.0406 & 0.9948 \\
\hline$\triangle \mathrm{ROSE}$ & 0.9729 & 0.9889 & 0.9500 & 0.8676 & 0.9754 & 0.9842 & 1.1477 & 0.9838 \\
\hline$\triangle \mathrm{OME}$ & 0.9891 & 1.0267 & 0.9898 & 0.9947 & 1.0246 & 0.9900 & 1.0079 & 1.0033 \\
\hline \multicolumn{9}{|c|}{ State-Owned Commercial Banks } \\
\hline$\triangle \mathrm{TFP}$ & 1.0324 & 0.9794 & 1.1243 & 0.9935 & 1.0874 & 0.9383 & 0.9710 & 1.0180 \\
\hline$\Delta$ Tech & 1.5403 & 0.7874 & 3.1193 & 1.6395 & 1.0363 & 1.5496 & 0.9155 & 1.5125 \\
\hline$\Delta \mathrm{Eff}$ & 0.8043 & 1.3469 & 0.5897 & 0.7106 & 1.0497 & 0.7539 & 1.1618 & 0.9167 \\
\hline$\triangle \mathrm{OTE}$ & 1.0000 & 0.9962 & 1.0039 & 1.0000 & 1.0000 & 1.0000 & 1.0000 & 1.0000 \\
\hline$\triangle \mathrm{ROSE}$ & 0.8122 & 1.3614 & 0.5863 & 0.7185 & 1.0497 & 0.7644 & 1.1700 & 0.9232 \\
\hline$\triangle \mathrm{OME}$ & 0.9845 & 0.9863 & 1.0113 & 0.9991 & 1.0000 & 0.9916 & 0.9917 & 0.9949 \\
\hline \multicolumn{9}{|c|}{ Foreign and Joint-Venture Banks } \\
\hline$\triangle T F P$ & 1.4411 & 0.9280 & 1.3845 & 1.0733 & 1.4035 & 0.8339 & 0.9648 & 1.1470 \\
\hline$\Delta$ Tech & 1.4200 & 1.1767 & 2.9274 & 1.4634 & 1.2190 & 1.1072 & 0.7710 & 1.4407 \\
\hline$\Delta \mathrm{Eff}$ & 0.9593 & 0.8500 & 0.7040 & 0.7204 & 1.2031 & 0.7732 & 1.2925 & 0.9289 \\
\hline$\triangle \mathrm{OTE}$ & 1.0654 & 0.9996 & 1.0160 & 0.9079 & 1.0420 & 0.9649 & 1.0355 & 1.0044 \\
\hline$\triangle \mathrm{ROSE}$ & 1.0341 & 0.8532 & 0.6883 & 0.8054 & 1.1686 & 0.8026 & 1.2497 & 0.9431 \\
\hline$\triangle \mathrm{OME}$ & 0.9876 & 0.9967 & 0.9991 & 0.9934 & 1.0050 & 0.9996 & 1.0039 & 0.9979 \\
\hline \multicolumn{9}{|l|}{ All } \\
\hline$\triangle \mathrm{TFP}$ & 1.0882 & 1.1782 & 1.0527 & 0.9978 & 1.1785 & 1.0592 & 0.9973 & 1.0789 \\
\hline$\Delta$ Tech & 1.2551 & 1.1945 & 1.7250 & 1.2966 & 1.1094 & 1.3381 & 0.8704 & 1.2556 \\
\hline$\Delta \mathrm{Eff}$ & 0.9277 & 1.0718 & 0.8450 & 0.8018 & 1.0784 & 0.8482 & 1.2089 & 0.9688 \\
\hline$\triangle \mathrm{OTE}$ & 0.9950 & 1.0243 & 0.9901 & 0.9663 & 1.0404 & 0.9284 & 1.0341 & 0.9969 \\
\hline$\triangle \mathrm{ROSE}$ & 0.9587 & 1.0228 & 0.8606 & 0.8374 & 1.0136 & 0.9268 & 1.1654 & 0.9693 \\
\hline$\triangle \mathrm{OME}$ & 0.9882 & 1.0167 & 0.9942 & 0.9951 & 1.0183 & 0.9916 & 1.0050 & 1.0013 \\
\hline
\end{tabular}

Notes: $\Delta \mathrm{TFP}=\Delta \mathrm{Tech} \times \Delta \mathrm{Eff}$ and $\Delta \mathrm{Eff}=\Delta \mathrm{OTC} \times \Delta \mathrm{ROSE} \times \mathrm{OME}$. $\Delta \mathrm{TFP}$ is Total Factor Productivity change; $\Delta$ Tech is technology change; $\Delta \mathrm{Eff}$ is efficiency change; $\Delta \mathrm{OTC}$ is output-oriented technical efficiency change; $\Delta \mathrm{ROSE}$ is residual output-oriented scale efficiency change; $\triangle \mathrm{OME}$ is output-oriented mix efficiency change. 
It is clear that the source of productivity gain in Vietnamese banks is the technological progress which has recorded a growth rate by $25.56 \%$ annually. This high growth rate is attributed to the boom of internet banking, and in line with the rise of intelligent devices such as smartphones. Besides, new standards of loan classification, capital adequacy and risk management are widely applied which helps banks reduce bad loans and increase their revenue. These results seem to contrast with those proposed by Nguyen and Simioni (2015). These authors used the data of Vietnamese banks from 2008 to 2012 and the Färe-Primont TFP index to measure the productivity change and found a technical regression despite the dissemination of important technology innovations. It is assumed that this innovation needs a long time to take effect and the later period (20112018) has been beneficial from investments in technology in the previous period (2008-2012).

The 2011-2018 period has witnessed a regress of efficiency when the component index of this measure stands at 0.9688 , which is equivalent to a $3.22 \%$ decrease annually. The other two elements (technical and mix efficiency) seem unchanged (their estimates are 0.9969 decline of efficiency is due to its scale component with the estimate of scale efficiency change standing at 0.9693 when the and 1.0013, respectively). Among three bank cohorts, state-owned banks are the most negatively impacted by the regress of scale efficiency with a substantial decrease at 7.68\%/year. The contractionary monetary policy conducted since 2011 aims to curb credit growth and also deteriorates the scale efficiency of Vietnamese banks as a consequence.

\section{Conclusion}

Using the Hicks-Moorsteen TFP index, this study is to examine the productivity change and its component changes in Vietnamese banking sector during the restructuring period (2011-2019). The outcomes reveals a growth of the sector's productivity due to technical progress when the overall efficiency declines. While technical and mix efficiency remain unchanged, a substantial decrease of scale efficiency is recorded and seen as the major source of overall efficiency regress. When FJVBs achieve the highest growth rate of productivity, public banks are the most influenced by the decrease of scale efficiency and this leads to an insignificant increase of SOCBs' productivity. SOCBs are technically the most efficient compared with other two bank groups (JSBs and FJVBs).

In general, the impact of restructuring measures on bank productivity is positive across different types of bank ownership. A progress of technology across three bank groups is due to the adoption of high-tech in banking and applying new standards on capital adequacy, and risk management which improves the quality of bank governance. However, the restructuring program also declines bank scale efficiency because of limited credit growth.

A number of policy implications are proposed to improve the Vietnamese banking sector productivity based on this research's findings. First, high-tech in banking should be further applied in the Vietnamese banks. High-tech is expected to diversify bank services provided to customers due to easy access and low transaction costs (Phan, Narayan, Rahman, and Hutabarat, 2019). Second, the SBV should remove limitations on credit growth to improve the scale efficiency; nonetheless, this action should be conducted cautiously to avoid the return of bad loans.

\section{References}

Altunbaş, Y., \& Marqués, D. (2008). Mergers and acquisitions and bank performance in Europe: The role of strategic similarities. Journal of Economics and Business, 60(3), 204-222. https:// doi.org/10.1016/j.jeconbus.2007.02.003

Ariff, M., \& Can, L. (2009). IMF Bank-Restructuring Efficiency Outcomes: Evidence from East Asia. Journal of Financial Service Research, 32(2), 167-187. https://doi.org/10.1007/ s10693-008-0047-2

Balk, B. M. (2012). Price and quantity index numbers: models for measuring aggregate change and difference. Cambridge, UK: Cambridge University Press.

Batten, J., \& Vo, X. V. (2019). Determinants of bank profitabilityEvidence from Vietnam. Emerging Markets Finance and Trade, 55(6), 1417-1428. https://doi.org/10.1080/154049 6x.2018.1524326

Berger, A. N., \& Turk-Ariss, R. (2015). Do depositors discipline banks and did government actions during the recent crisis reduce this discipline? An international perspective. Journal of Financial Services Research, 48(2), 103-126. https://doi. org/10.1007/s10693-014-0205-7

Bui, T. N. (2020). Financial Development in Vietnam: An Overview. Journal of Asian Finance, Economics and Business, 7(9), 169178. doi:10.13106/jafeb.2020.vol7.no9.169

Calderon, C., \& Schaeck, K. (2016). The effects of government interventions in the financial sector on banking competition and the evolution of zombie banks. Journal of Financial and Quantitative Analysis, 51(4), 1391-1436. https://doi. $\operatorname{org} / 10.1017 / \mathrm{s} 0022109016000478$

Claessens, S., Ghosh, S. R. \& Mihet, R. (2013). Macro-prudential policies to mitigate financial system vulnerabilities. Journal of International Money and Finance, 39, 153-185. https://doi. org/10.1016/j.jimonfin.2013.06.023

Dang, V. D. (2020). Do non-traditional banking activities reduce bank liquidity creation? Evidence from Vietnam. Research in International Business and Finance, 101257. https://doi. org/10.1016/j.ribaf.2020.101257

Das, A., \& Ghosh, S. (2006). Financial deregulation and efficiency: An empirical analysis of Indian banks during the post reform 
period. Review of Financial Economics, 15(3), 193-221. https://doi.org/10.1016/j.rfe.2005.06.002

Duong, T. T. N., Phan, H. T., Hoang, T. N., \& Vo, T. T. T. (2020). The Effect of Financial Restructuring on the Overall Financial Performance of the Commercial Banks in Vietnam. Journal of Asian Finance, Economics and Business, 7(9), 75-84. https:// doi.org/10.13106/jafeb.2020.vol7.no9.075

Hakenes, H., \& Schnabel, I. (2010). Banks without parachutes: Competitive effects of government bail-out policies. Journal of Financial Stability, 6(3), 156-168. https://doi.org/10.1016/j. jfs.2009.05.006

Hasan, I., \& Xie, R. (2013). Foreign bank entry and bank corporate governance in China. Emerging Markets Finance and Trade, 49(2), 4-18. https://doi.org/10.2753/ree1540496x490201

Hsiao, H. C., Chang, H., Cianci, A. M., \& Huang, L. H. (2010). First financial restructuring and operating efficiency: evidence from Taiwanese commercial banks. Journal of Banking \& Finance, 34(7), 1461-1471. https://doi.org/10.1016/j. jbankfin.2010.01.013

Le, P. T., Harvie, C., Arjomandi, A., \& Borthwick, J. (2019). Financial liberalisation, bank ownership type and performance in a transition economy: The case of Vietnam. Pacific Basin Finance Journal, 57. https://doi.org/10.1016/j. pacfin.2019.101182

Linna, M. (1998). Measuring hospital cost efficiency with panel data models. Health economics, 7(5), 415-427. https://doi. org/10.1002/(SICI) 1099-1050(199808)7:5\%3C415::AIDHEC357\%3E3.0.CO;2-9

Llewellyn, D. T. (2002). An analysis of the causes of recent banking crises. European Journal of Finance, 8(2), 37-41. https://doi. org/10.1080/13518470110071182

Nguyen, H. D. H., \& Dang,V. D. (2020). Bank-Specific Determinants of Loan Growth in Vietnam: Evidence from the CAMELS Approach. Journal of Asian Finance, Economics and Business, 7(9), 179-189. https://doi.org/10.13106/jafeb.2020.vol7.no9.179

Nguyen, P. A., \& Simioni, M. (2015). Productivity and efficiency of Vietnamese banking system: new evidence using Färe-Primont index analysis. Applied Economics, 47(41), 4395-4407. https:// doi.org/10.1080/00036846.2015.1030565

O'Donnell, C. J. O. (2010). Measuring and decomposing agricultural productivity and profitability change. Australian Journal of Agricultural and Resource Economics, 54(4), 527560. https://doi.org/10.1111/j.1467-8489.2010.00512.x

O'Donnell, C. J. O. (2012). An aggregate quantity framework for measuring and decomposing productivity change. Journal of Productivity Analysis, 38(3), 255-272. https://doi.org/10.1007/ s11123-012-0275-1

Pestana, C. \& Williams, J. (2013). The random parameters stochastic frontier cost function and the effectiveness of public policy: Evidence from bank restructuring in Mexico. International Review of Financial Analysis. 30, 98-108. https:// doi.org/10.1016/j.irfa.2013.06.006

Phan, D. H. B., Narayan, P. K., Rahman, R. E., and Hutabarat, A. R. (2019). Do financial technology firms influence bank performance?. Pacific-Basin Finance Journal, 101210. https:// doi.org/10.1016/j.pacfin.2019.101210

Pincus, J. (2009). Sustaining Growth in Difficult Times. ASEAN Economic Bulletin, 26(1), 11-24. https://doi.org/10.1355/ae26$1 \mathrm{~b}$

Shephard, R.W. (1953). Cost and production functions. Prinston, NJ: Princeton University Press.

Williams, J. (2012). Efficiency and market power in Latin American banking. Journal of Financial Stability, 8(4), 263-276. https:// doi.org/10.1016/j.jfs.2012.05.001

Williams, J. \& Nguyen, N. (2005). Financial liberalisation, crisis , and restructuring: A comparative study of bank performance and bank governance in South East Asia. Journal of Banking and Finance, 29, 2119-2154. https://doi.org/10.1016/j. jbankfin.2005.03.011

World Bank. (2014). Financial Sector Assessment. World Bank Vietnam Report No. 92618. Washington, DC: The World Bank.

World Bank. (2019). Vietnam: Strengthening Banking Sector Soundness and Development. World Bank Vietnam Report No. PIDC194870. Washington, DC: The World Bank. 